\title{
A comparison of the results of carpal tunnel release in patients in different
}

\section{age groups}

\section{Porównanie wyników leczenia zespołu kanału nadgarstka w różnych grupach wiekowych}

\author{
Andrzei Żyluk, Piotr Puchalski \\ Department of General and Hand Surgery, Pomeranian Medical University in Szzzecin, Szzzecin, Poland
}

Neurologia i Neurochirurgia Polska 2013; 47, 3: 241-246

DOl: 10.5114/ninp.2013.35486

\begin{abstract}
Background and purpose: The age of the patient at the onset of the disease may influence its course and outcome of the treatment. The objective of this study was to compare outcomes of carpal tunnel release in patients in different age ranges.

Material and methods: The records from the register of patients with carpal tunnel syndrome who were operated on in the authors' department over a period of two years (between 2009 and 2011) were analyzed. A total of 386 patients with carpal tunnel syndrome, 322 female (83\%) and 64 male (17\%) with a mean age of 57 (range: $30-81$ ) years were divided into three sub-groups according to their age: 40 years or less $(n=$ $=28), 41-65$ years $(n=248)$ and over 65 years $(n=73)$. All patients received mini-open carpal tunnel release. The results were assessed at 6 months after the operation by the Levine questionnaire and measurements of grip and pinch strengths as well as sensation of a light touch by the filament test.

Results: At the six-month follow-up, all patients showed significant resolution of symptoms as assessed by the Levine symptom score (from 3.3 to 1.4 ) and significant improvement of the dexterity of the hand, as assessed by the Levine function score (from 3.0-3.2 to 1.6-1.8). All patients showed significant improvement of sensation of a light touch and increase of grip and pinch strengths. However, patients older than 60 years showed less improvement of the total grip strength of the hand.
\end{abstract}

Conclusion: Patients with carpal tunnel syndrome at any age may expect a similar benefit from surgery.

Key words: carpal tunnel syndrome - treatment, outcome, older age.

\section{Streszczenie}

Wstęp i cel pracy: Wiek pacjentów w momencie zachorowania może mieć wpływ na przebieg choroby i wyniki jej leczenia. Celem pracy było porównanie wyników leczenia operacyjnego zespołu kanału nadgarstka u osób w różnych grupach wiekowych.

Materiał i metody: Analizie poddano dane $\mathrm{z}$ rejestru chorych z zespołem kanału nadgarstka, którzy byli operowani w ośrodku autorów w latach 2009-2011. Grupę 386 chorych z ze społem kanału nadgarstka, 322 kobiety (83\%) i 64 mężczyzn (17\%), których średnia wieku wynosiła 57 lat (zakres: 30-81 lat), podzielono na 3 podgrupy wiekowe: $\leq 40$ lat $(n=28)$, $41-65$ lat $(n=248)$ i $>65$ lat $(n=73)$. Wszyscy chorzy byli leczeni chirurgicznie za pomocą odbarczenia kanału nadgarstka metodą otwartą, małoinwazyjną. Wyniki oceniono po 6 miesiącach od operacji za pomocą kwestionariusza Levine'a, pomiarów siły chwytów: globalnego, klucza i trzypunktowego, oraz czucia dotyku testem filamentowym.

Wyniki: W badaniu kontrolnym po 6 miesiącach u wszystkich chorych zanotowano istotne zmniejszenie dolegliwości bólowych i poprawę sprawności ręki (zmniejszenie średniej punktacji objawowej kwestionariusza Levine'a z 3,3 do 1,4 i czynnościowej z 3,0-3,2 do 1,6-1,8). U wszystkich chorych istotnie poprawiło się czucie dotyku i wzrosła siła chwytów. Poprawa siły chwytu globalnego była jednak najmniejsza w grupie osób powyżej 60 lat.

Wniosek: Wyniki operacyjnego leczenia zespołu kanału nadgarstka są podobnie korzystne u chorych w różnych grupach wiekowych.

Słowa kluczowe: zespół kanału nadgarstka - leczenie, wyniki leczenia, wiek zachorowania.

Correspondence address: Prof. Andrzej Żyluk, MD, Department of General and Hand Surgery, ul. Unii Lubelskiej 1, 71-252 Szczecin, Poland, phone/fax: +48914253196,e-mail: azyluk@hotmail.com

Received: 12.07.2012; accepted: 16.10.2012 


\section{Introduction}

Carpal tunnel syndrome (CTS) is the most common compression neuropathy, affecting about $6 \%$ of women aged over 40 years $[1,2]$. Although several predisposing factors have been identified, i.e. diabetes mellitus, hypothyroidism, and rheumatoid arthritis, the idiopathic form is the most common $[3,4]$. The syndrome affects mostly women in middle and older age with two peaks observed at 40-50 years and $>70$ years.

The clinical course of CTS is not uniform and its natural history is complex. A proportion of patients experience mild disease with symptoms and signs being not particularly troublesome and these patients do not seek medical advice for many years. In contrast, there are patients who develop a serious syndrome within 2-3 months, having severe symptoms and abnormal electrophysiological studies [3-5]. The age of the patient at the onset of the disease may influence its course and outcome of the treatment. The borderline of 'older age' is variable, with a tendency to move up with civilization development. According to the contemporary WHO criteria, the 'older age' lower limit for developed countries is assigned at 75 years. One may expect poorer outcomes (lower improvement) after carpal tunnel release in older patients, particularly in the functional aspect, because hand dexterity is naturally decreased at this age. Another problem may be associated with reduced capacity of elderly patients to understand and complete questionnaires used in outcome measurement (i.e. the Levine questionnaire), because of reduced intellectual dexterity (dementia) [6]. In a recent study by Nawrot et al. [7] this tendency was not confirmed, but the borderline between younger and older patients' age was very low, at 45 years.

The objective of this study was to compare clinical outcomes of carpal tunnel release between groups of patients in different age ranges.

\section{Material and methods}

The records from the register of patients with CTS who were operated on in the authors' department over a period of two years (between 2009 and 2011) were analysed. All patients operated on in this period were included, regardless of the associated diseases (diabetes, hypothyroidism) or previous injury to the affected hand. Only patients with recurrent disease $(n=6)$ were ex cluded.

There were 386 patients, 322 female $(83 \%)$ and 64 male (17\%) with a mean age of 57 (range: 30-81) years, with the mean disease duration of 46 months (range: 3-240 months). The diagnosis of CTS was made based on 'classical' clinical history, symptoms and signs (Table 1). In 169 patients (44\%), for various reasons, electrodiagnostic studies were additionally performed, confirming the diagnosis. The group was divided into three sub-groups, according to age: (1) 40 years or un$\operatorname{der}(n=28), 41-65$ years $(n=248)$ and over 65 years $(n=73)$.

Each patient was assessed one day before the operation, and followed up at 1 and 6 months. The person who did the assessments was blind to the clinical status of the patient. The following measurements were used: 1) Digital sensibility with the Semmes-Weinstein monofilament test. Measurements were carried out on the thumb, index and middle fingers. The results were expressed in ranks: (5) touch detectable with a green filament; (4) with blue filament; (3) with purple filament; (2) with red filament; and (1) with a black filament. The measurements from each finger were added and then divided by three, finally giving the sensory index. A sensory index score of 5 indicated normal sensation in all three digits, while a score of 1 indicated no sensation in these digits.

2) Motor tests: total grip, key- and three-point pinch strengths were measured with a Jamar dynamometer and pinch-meter from the set of DataLink (Biometrics and $\mathrm{Co}_{\mathrm{L}} \mathrm{Ltd}$, Gwent, UK). The results were given as a proportion of the strength of the other hand.

3) All patients completed the Levine questionnaire [8].

All patients received mini-invasive carpal tunnel release under local anaesthesia, with the use of a tourniquet. The outcomes in patients within age groups were compared. The Levine scores (symptom and function)

Table 1. Constellation of symptoms and signs typical for carpal tunnel syndrome

Pain and numbness in the hand, which wakes the patient at night. Feeling of oedema of the digits

Occurrence of these symptoms in digits/hand innervated by a median nerve

Occurrence of these symptoms in the day, at manual work or static grip with flexed wrist

Relief of symptoms after shaking or rubbing the hand

Weaker grip, reduced dexterity of the hand 
were considered to be primary outcome measures. The statistical significance of differences in outcomes in either group was examined with the non-parametric Kruskal-Wallis test (all variables were non-normally distributed).

\section{Results}

A comparison of demographic and clinical data for each group showed significant differences in age (obvious), duration of the disease (longer in the oldest and middle-age subgroups, compared to the youngest) and in involvement of the dominant hand (Table 2).

Pre-operative comparison of considered variables (Table 3) showed significant differences between the groups in perception of touch with the Semmes-Weinstein filaments, weaker in the youngest, followed by middle-age and the oldest group (sensory index 3.7 vs. 3.3 vs. 3.0, respectively, $p<0.001$ ). This difference, although significant, was not clinically meaningful, because the minimal detectable difference of the sensory index is considered to be 1.0. There were also significant differences in three-point pinch (weaker in the youngest group: $77 \%$ vs. $89 \%$ and $84 \%, p<0.05)$ and function Levine scores, suggesting greater impairment in the youngest group (3.2 vs. 3.0 and 3.0). This latter difference, however, was not clinically meaningful, because the minimal detectable difference of the Levine score is considered to be 1.0 .

Post-operative assessment after 6 months (Table 4) showed moderate (compared to baseline) improvement of the perception of touch with the Semmes-Weinstein filaments. The differences in sensory index were statistically significant, favouring the youngest group, followed by the middle-age and the oldest (sensory index: 4.8 vs. 4.5 vs. 4.1 , respectively, $p<0.001$ ). As in baseline measurements, these differences, although statistically significant, were not of clinical importance.

With regard to motor tests, the total grip strength showed the greatest improvement (baseline vs. final assessment) in the youngest group ( $85 \%$ vs. $138 \%, p<0.001$ ), followed by the middle-age ( $87 \%$ vs. $106 \%, p<0.001$ ), with only minimal (but statistically significant) gain noted in the oldest group $(82 \%$ vs. $87 \%, p=0.05)$. The difference in the final total grip strength between the youngest and middle-age versus the oldest group was statistically

Table 2. Comparison of characteristics of groups of studied patients with carpal tunnel syndrome

\begin{tabular}{|c|c|c|c|c|c|}
\hline \multirow[t]{2}{*}{ Variable } & \multirow[t]{2}{*}{ Total } & \multicolumn{3}{|c|}{ Age sub-groups } & \multirow[t]{2}{*}{ p-value } \\
\hline & & $\leq 40$ years & 41-65 years & $>65$ years & \\
\hline Number of patients & 386 & 31 & 278 & 77 & \\
\hline Age [years]; mean & 57 & 34 & 55 & 75 & $<0.001$ \\
\hline Gender (female/male) & $322 / 64$ & $29 / 2$ & $233 / 45$ & $60 / 17$ & 0.34 \\
\hline $\begin{array}{l}\text { Duration of carpal tunnel syndrome } \\
\text { symptoms [months]; mean }\end{array}$ & 46 & 29 & 58 & 60 & $<0.05$ \\
\hline Hand involved: dominant/non-dominant & $249 / 137$ & $26 / 5$ & $184 / 94$ & $39 / 38$ & \\
\hline
\end{tabular}

Statistical calculations by ANOVA Kruskal-Wallis test.

Table 3. Pre-operative (baseline) comparison of considered variables among age sub-groups*

\begin{tabular}{|c|c|c|c|c|}
\hline \multirow[t]{2}{*}{ Variable } & \multicolumn{3}{|c|}{ Age sub-groups } & \multirow[t]{2}{*}{ p-value } \\
\hline & $\begin{array}{c}\leq 40 \text { years } \\
(n=31)\end{array}$ & $\begin{array}{c}41-65 \text { years } \\
(n=278)\end{array}$ & $\begin{array}{c}>65 \text { years } \\
(n=77)\end{array}$ & \\
\hline Sensory index (1-5) & $3.7(0.98)$ & $3.3(0.87)$ & $3.0(0.84)$ & $<0.001$ \\
\hline Total grip strength (\%) & $85(37)$ & $87(43)$ & $82(31)$ & 0.77 \\
\hline Key pinch strength (\%) & $87(39)$ & $89(33)$ & $83(34)$ & 0.33 \\
\hline Three-point strength (\%) & $73(38)$ & $89(38)$ & $84(38)$ & $<0.05$ \\
\hline Symptom Levine score (1-5) & $3.3(0.58)$ & $3.2(0.68)$ & $3.2(0.67)$ & 0.51 \\
\hline Function Levine score (1-5) & $3.0(0.67)$ & $3.0(0.69)$ & $3.2(0.69)$ & $<0.05$ \\
\hline
\end{tabular}

*Data are presented as means (standard deviations). 
Table 4. Comparison of considered variables at 6 months post-operatively among age sub-groups

\begin{tabular}{|c|c|c|c|c|}
\hline \multirow[t]{2}{*}{ Variable } & \multicolumn{3}{|c|}{ Age sub-groups } & \multirow[t]{2}{*}{ p-value } \\
\hline & $\begin{array}{c}40 \text { years } \\
(n=31)\end{array}$ & $\begin{array}{c}41-65 \text { years } \\
(n=278)\end{array}$ & $\begin{array}{c}>65 \text { years } \\
(n=77)\end{array}$ & \\
\hline Sensory index (1-5) & $4.8(0.46)$ & $4.5(0.84)$ & $4.1(0.89)$ & $<0.001$ \\
\hline Sensory index $\Delta 0-6$ months (\%) & $38(39)$ & $47(89)$ & $49(70)$ & 0.47 \\
\hline Total grip strength (\%) & $138(44)$ & $106(53)$ & $87(27)$ & 0.05 \\
\hline Key pinch strength (\%) & $122(43)$ & $102(36)$ & $93(22)$ & 0.18 \\
\hline Three-point strength (\%) & $98(36)$ & $97(41)$ & $93(34)$ & 0.70 \\
\hline Symptom Levine score (1-5) & $1.4(0.53)$ & $1.4(0.54)$ & $1.4(0.51)$ & 0.95 \\
\hline Function Levine score (1-5) & $1.6(0.49)$ & $1.6(0.53)$ & $1.8(0.78)$ & 0.08 \\
\hline
\end{tabular}

Data are presented as means (standard deviations).

significant, disfavouring the oldest group. Key-pinch strength also showed the greatest improvement in the youngest group ( $87 \%$ vs. $122 \%, p<0.001)$, followed by the middle-age ( $89 \%$ vs. $102 \%, p<0.001$ ) and the oldest $(83 \%$ vs. $93 \%, p=0.01)$. The differences between the age groups failed to reach statistical significance. Threepoint pinch strength also showed the greatest improvement in the youngest group ( $73 \%$ vs. $98 \%, p<0.001)$, followed by the middle-age ( $89 \%$ vs. $97 \%, p=0.01)$ and the oldest ( $84 \%$ vs. $93 \%, p=0.008$ ), but these differences between groups were not statistically significant.

An assessment at 6 months showed remarkable and statistically significant reduction of the Levine symptom and function scores (compared to baseline) in all the age groups. There were no differences between the age groups with regard to final symptom Levine scores, suggesting similar reduction of pain and numbness. Likewise, the final function Levine scores did not differ significantly between the groups, with minimally higher scores in the oldest one.

Complications, such as nerve or vessel injury, were not observed in either group. Superficial wound infection which subsided after oral antibiotic administration was observed in seven patients (1.8\%). Symptoms and signs of mild complex regional pain syndrome were noted in two patients but resolved within two months after a course of physiotherapy.

\section{Discussion}

All patients showed significant resolution of CTS symptoms at 6 months, as assessed by the Levine symptom score. They also showed a significant improvement of the dexterity of the hand, as assessed by the Levine function score. The main objective of this study was to compare the results of carpal tunnel release in patients in three different age groups. As the Levine scores were considered the primary outcome measure, the results of our study show that age of patients has no significant effect on the results of surgical treatment of carpal tunnel syndrome or - to put it another way - patients of any age may expect a similar benefit from surgery.

The results of this study showed significantly weaker grip and pinch strengths in the oldest patients compared to the other groups at 6-month assessment. The gain in power of the hand (baseline to final) was the lowest in the oldest patients, suggesting reduced capacity of regeneration of impaired function of the muscles. This tendency was not observed in pre-operative measurements, which showed motor function to be equally impaired in all groups, regardless of age (Table 3 ). This weaker grip and pinch strengths of the hand, however, did not translate into poorer hand function, because improvement of the dexterity as a result of surgery (as sessed by the function Levine score) was similar in all the age groups.

There is conflicting evidence on the effect of age of patients with CTS on surgical outcomes, although most studies suggest that it has a bearing on the result [6,9-11].

Porter et al. [6] compared the outcomes of carpal tunnel release in 46 CTS patients aged 60 years or less with 41 CTS patients over 60 years of age. The Levine scores were considered the primary outcome measure. At the six-month post-operative assessment, improvement was noted in both groups compared to baseline values, but it was less significant in the older group. For the younger group, the Levine symptom score decreased from 3.1 (baseline) to 1.6 (at 6 months), whereas for the 
older group it decreased from 2.7 to 1.6 , respectively. The Levine function scores decreased from 2.3 to 1.5 in the younger group and from 2.3 to 1.8 in the older group. The differences between the groups were statistically significant. The authors also noted significant improvement in nerve conduction after the operation in both groups but they were less expressed in the older one. They concluded that age is a clear factor affecting the outcome after carpal tunnel release [6].

Hobby et al. [10] and Townshend et al. [9] found that in patients over 60-70 years, the greater the severity of symptoms preoperatively, the less successful the outcome. This finding was not confirmed in our study. These authors suggest that although outcomes in older patients may be less predictable, the majority of them experience objective benefit from carpal tunnel release.

Nawrot et al. [7] reported similar outcomes of carpal tunnel release (assessed at one and six months post-operatively) in 33 patients, of whom eight were aged 45 years or less and 27 were older than 45 years. They noted only worse results in patients with the disease lasting longer than 6 months.

The results of our study are not fully consistent with the above-mentioned reports, except the report by $\mathrm{Na}-$ wrot et al. Although improvement of the grip and pinch strengths was smaller in the oldest group, the difference in relation to younger sub-groups was statistically significant only for the total grip strength and did not translate into significantly lower Levine scores (primary outcome measure). The advantage of our survey is that it was based on a great number of patients, much greater than reported in earlier studies. It was also conducted following clear methodology, including measurements of subjective and objective parameters. The flaws include the retrospective nature of the study and inclusion of all cases of CTS (except recurrent ones) with no selection of idiopathic cases from those with associated diseases such as diabetes, hypothyroidism or rheumatoid arthritis. This, however, may be considered an advantage, because of showing the benefit from carpal tunnel release in older patients, regardless of the aetiology of the disease.

Many factors may affect outcomes of carpal tunnel surgery, including duration of symptoms, clinical severity, co-morbidity (diabetes, hypothyroidism), operative technique (classical open, mini-open, endoscopic), etc. A systematic review of the possible role of these factors showed no conclusive results. Diabetes was found to worsen outcomes in some studies, whereas it did not in others [12]. Likewise, opinions on the effect of age, gender, duration of symptoms and clinical severity of the syndrome vary on this point [11]. It was not our aim to conduct a multivariate analysis of possible factors influencing the outcomes of carpal tunnel surgery, but to focus on a single, specific parameter: patient's age.

One may also question the accuracy of CTS diagnosis in our series, which was based on purely clinical grounds. Controversy persists regarding the need for electrodiagnostic studies to confirm the diagnosis. Some believe that they are mandatory to confirm the diagnosis; more and more surgeons, however, consider nerve conduction studies to be superfluous in typical cases of CTS and are convinced that a confident diagnosis can be made based on the history and clinical findings alone $[13,14]$. We share this opinion and follow it in our clinical practice. Some studies have shown that performing nerve conduction studies did not improve the outcomes of surgery for CTS $[14,15]$. Thus, it is suggested that they are desirable only in doubtful cases, in patients with atypical symptoms or unclear course of the disease [14-16]. Moreover, Witt et al. [17] reported that 25\% of patients with typical symptoms of CTS had normal conduction in the median nerve. It was found in other studies that operative treatment of these patients results in resolution of symptoms and clinical recovery $[18,19]$.

Another matter of concern may be the severity of the syndrome at presentation, which might affect the results of the treatment. However, as has been shown in some studies, electrodiagnostic findings correlate statistically significantly with Levine scores $[5,17,20,21]$. Thus, the assessment of the clinical severity of carpal tunnel syndrome can be equally good based on the Levine score, as it was done in our study.

\section{Conclusions}

Age of patients has no significant effect on the effectiveness of surgical treatment of CTS or - to put it another way - patients of any age may be similarly satisfied with surgery. However, patients older than 65 years showed less improvement of the power of the hand.

\section{Disclosure}

Authors report no conflict of interest.

\section{References}

1. Zyluk A., Strychar J. A comparison of two limited open techniques for carpal tunnel syndrome release. J Hand Surg Br 2006; 31: 466-472. 
2. Chang C.W., Wang Y.C., Chang K.F. A practical electrophysiological guide for non-surgical and surgical treatment of carpal tunnel syndrome. J Hand Surg Eur Vol 2008; 33E: 32-37.

3. Żyluk A., Puchalski P. Historia naturalna zespołu kanału nadgarstka: przegląd piśmiennictwa. Chir Narz Ruchu Otrop Pol 2010; 75: 261-266.

4. Ortiz-Corredor F., Enríquez F., Díaz-Ruíz J., et al. Natural evolution of carpal tunnel syndrome in untreated patients. Clin Neurophysiol 2008; 119: 1373-1378.

5. Choi S.J., Ahn D.S. Correlation of clinical history and electrodiagnostic abnormalities with outcome after surgery for carpal tunnel syndrome. Plast Reconstr Surg 1998; 102: 2374-2380.

6. Porter P., Venkateswaran B., Stephenson H., et al. The influence of age on outcome after operations for carpal tunnel syndrome. J Bone Joint Surg Br 2002; 84B: 688-691.

7. Nawrot P., Nowakowski A., Bartochowski L., et al. Wpływ wieku chorego i czasu trwania neuropatii na wyniki leczenia operacyjnego neuropatii uciskowych kończyny górnej. Chir Narz Ruchu Otrop Pol 2008; 73: 116-128.

8. Levine D.W., Simmons B.P., Koris M.J., et al. A self-administered questionnaire for the assessment of severity of symptoms and functional status in carpal tunnel syndrome. $J$ Bone Joint Surg Am 1993; 75A: 1585-1592.

9. Townshend D.N., Taylor P., Gwynne-Jones D.P. The outcome of carpal tunnel decompression in eldery patients. J Hand Surg 2005; 30A: 500-505.

10. Hobby J.L., Venkatesh R., Motkur P. The effect of age and gender upon symptoms and surgical outcomes in carpal tunnel syndrome. J Hand Surg Br 2005; 30B: 599-604.

11. Turner A., Kimble F., Gulyás K., et al. Can the outcome of open carpal tunnel release be predicted. ANZ J Surg 2010; 80: 50-54.

12. Żyluk A., Puchalski P. A comparison of outcomes of carpal tunnel release in diabetic and non-diabetic patients. $J$ Hand Surg Eur 2013; 38: 485-488

13. Ebskov L.B., Boeckstyns M.E., Sørensen A.I. Operative treatment of carpal tunnel syndrome in Denmark: results of a questionnaire. J Hand Surg 1997; 22B: 761-763.

14. Finsen V., Russwurm H. Neurophysiology not required before surgery for typical carpal tunnel syndrome? J Hand Surg 2001; 26B: 61-64.

15. Concannon M.J., Gainor B., Petroski G.F., et al. The predictive value of electrodiagnostic studies in carpal tunnel syndrome. Plast Reconstr Surg 1997; 100: 1452-1458.

16. Smith N.J. Nerve conduction studies for carpal tunnel syndrome. Essential prelude to surgery or unnecessary luxury? $J$ Hand Surg Br 2002; 27B: 83-85.

17. Witt J.C., Hentz J.G., Stevens J.C. Carpal tunnel syndrome with normal nerve conduction studies. Muscle Nerve 2004; 29: 515-522.

18. Grundberg A.B. Carpal tunnel decompression in spite of normal electromyography. J Hand Surg Am 1983; 8A: 348-349.

19. Louis D., Hankin F.M. Symptomatic relief following carpal tunnel decompression with normal electromyographic studies. Orthopedics 1987; 10: 434-436.

20. You H., Simmons Z., Freivalds A., et al. Relationships between clinical symptom severity scales and nerve conduction measures in carpal tunnel syndrome. Muscle Nerve 1999; 22: 497-501.
21. Georgiew F., Maciejczak A., Otfinowska E. Ocena stopnia nasilenia dolegliwości subiektywnych towarzyszących zespołowi kanału nadgarstka w zależności od nasilenia zmian stwierdzanych badaniem elektroneurograficznym. Rehab Med 2010; 14: 17-22. 